\title{
Are Entrepreneurial Capabilities and Prior Knowledge the Silver Bullet for the Generation of New Digital Venture Ideas in a Digital Context?
}

\author{
Meifang Yao, School of Management, Jilin University, China \\ Dan Ye, School of Management, Jilin University, China \\ Gao Yang, School of Economics and Management, Dalian University of Technology, China \\ Hui Shi, Computer Information Systems Department, California State Polytechnic University, USA \\ Xianrong Zheng, Old Dominion University, USA \\ iD https://orcid.org/0000-0003-2695-9642
}

\begin{abstract}
Digital technology has had an important impact on entrepreneurship. It has changed the uncertain nature of the process of new venture idea generation, and it has also brought unprecedented opportunities for the generation of new digital venture ideas. In order to explore how startups can deal with major challenges brought by digital technology and create new digital venture ideas, this paper focuses on micro level entrepreneurial actions and constructs a theoretical model of the relationship among networking capabilities, IT capabilities, prior knowledge, and new digital venture ideas. Furthermore, through the hierarchical linear regression analysis of 278 sample data, the paper finds that in the context of digitalization, both networking capabilities and IT capabilities have a positive impact on the generation of new digital venture ideas. In addition, prior knowledge plays an important role in moderating the relationship between IT capabilities and new digital venture ideas. This paper conducts both theoretical and empirical analysis to explore how startups can build new digital venture ideas in the context of digitalization, which guides small and medium-sized enterprises in responding to new challenges.
\end{abstract}

\section{KEYWORDS}

IT Capability, Networking Capability, New Digital Venture Ideas, Prior Knowledge

\section{INTRODUCTION}

In recent years, digital technologies featuring hierarchical modular structure (von Briel et al., 2018) and granular structure (Kallinikos et al., 2013), such as mobile computing, cloud computing (Aceto et al., 2020; Gandhi \& Singh, 2020; Yang, 2019), social media, 3D printing (Fatma et al., 2020; Haleem \& Javaid, 2019), data management analytics (Haenlein et al., 2019; Law \& Chung, 2020; Mohanty \& Shankar, 2019), have been widely used in all aspects of the entrepreneurial field. These 
digital technologies have changed the inherent uncertainty of the entrepreneurial process and the way to deal with this uncertainty. Similarly, digital technologies have had a significant impact on new venture ideas and the studies on new venture ideas (Chalmers et al., 2019). To the best of our knowledge, if the product/service of new venture ideas rely on digital technologies, then we consider them as new digital venture ideas.

Entrepreneurship creativity, as the key to producing new ideas, shows the direction of entrepreneurship. Given the importance of venture ideas, there should be a solid theoretical foundation for its generation (Lomberg et al., 2017), especially for digital venture ideas. The existing research on digital venture ideas is still in the stage of theoretical concept construction, mainly focusing on the definition of its concepts (von Briel, Recker \& Davidsson, 2018) and characteristics (von Briel, Davidsson \& Recker, 2018). Although there are some scholars who have initially explored the impact of certain types of digital technologies on venture ideas, such as blockchain (Chalmers et al., 2019) and crowdsourcing platforms (Blohm et al., 2013), these studies mostly explored the general impact of digital technology on digital venture ideas.

As the starting point of the entire entrepreneurial process, it is very important to trace how entrepreneurial ideas are generated (Shepherd, 2015). Therefore, how new entrepreneurial ventures deal with major digital challenges have attracted much attention in entrepreneurial research (von Briel et al., 2018). This article focuses on exploring how companies 1) deal with disruptive challenges brought by digital technology, 2) identify business opportunities from massive amounts of digital information and, 3) spark digital venture ideas.

Entrepreneurial ability is essential to identifying business opportunities. On the one hand, an open digital environment has built a global stakeholder network without the limitations of time and place, making it possible for people with different abilities to participate in the same entrepreneurial activity (Nambisan, 2017). Networking capability refers to the capacity of the new venture to identify, establish, coordinate and develop a variety of relationships with different roles in the market (Adler \& Kwon, 2002; Zou et al., 2010). In the digital environment, with support of digital technologies, it is important to build social relationships among entrepreneurs across regions and industries and to build digital social capital, which facilitates obtaining information about business opportunities and resources necessary to form digital venture ideas. On the other hand, IT capabilities, including information management capabilities (Simsek et al., 2009), information processing capabilities (Stevenson \& Jarillo, 1990), knowledge capabilities (Stoel \& Muhanna, 2009) and cross-channel capabilities (Stopford \& Baden-Fuller, 1994), are capabilities for entrepreneurs to obtain information related to business opportunities in a digital environment. In summary, networking capabilities and IT capabilities are both beneficial for sparking digital venture ideas.

In addition to obtaining information related to business opportunities, entrepreneurial cognition also has an important impact on venture ideas (Shepherd, 2015). In the digital environment, prior knowledge (Davenport \& Prusak, 1998) can be used to interpret the value of information (Gaglio \& Winter, 2009; Hajizadeh \& Zali, 2016). In the digital environment, it is easier for start-ups with rich prior knowledge to accurately identify the value of potential information in massive amounts of digital information. Therefore, prior knowledge helps to improve the efficiency of business opportunity identification and has an impact on creating digital venture ideas.

With focus on micro level entrepreneurial actions, this paper explores the impacts of networking capabilities and IT capabilities on creating digital entrepreneurial creativity and analyzes how does prior knowledge affects the process of digital venture idea generation. Here is the structure of this paper: first, we construct a theoretical model of the relationship among networking capabilities, IT capabilities, prior knowledge and new digital venture ideas; Second, we put forward the research hypothesis; Third, we conduct an empirical analysis of 278 sample data by using a hierarchical linear regression method. The results verify that, with digital technologies as an external enabler to spark and create digital venture ideas, the networking capabilities and IT capabilities make a positive contribution and play a key role; Fourth, we analyze the impacts of prior knowledge on digital venture ideas as 
well. This research not only explores how digital venture ideas are created (von Briel et al., 2018), but also provides important guidance for new startups within digital entrepreneurial environment.

\section{THEORETICAL BACKGROUND AND RESEARCH HYPOTHESIS}

\section{NEW DIGITAL VENTURE IDEAS}

New venture ideas are "imaginary combinations of product/service offerings; potential markets or users, and means of bringing these offerings into existence" (Davidsson, 2015). It is a preliminary insight presentation of potential entrepreneurial content in the future (Vogel, 2017), which outlines a blueprint and points out directions for the future. If the expected product/service of new venture ideas relies on digital technology, then the venture ideas are digital. In another word, new digital venture ideas either use digital technologies or are driven by these technologies (von Briel et al., 2018).

Digital technologies are editable, distributable and open (Ekbia, 2009; Kallinikos et al., 2013). Editability refers to the characteristic that digital products can be continuously modified and updated. Distributedness refers to the characteristic that digital products can be transmitted across resources and institutions. Openness refers to the accessibility of digital technologies. These characteristics of digital technologies have a huge impact on development and utilization of new digital venture ideas (Kallinikos et al., 2013; Nambisan, 2017). With more developed digital products, the editability, distributiveness and openness of digital technology or products make it possible to combine projects, processes, and programs, such as the combination of software, software components, and crossplatform production systems (Yoo et al., 2010).

Because of the characteristics of digital technology, the boundary of new digital venture idea participants and creating process becomes blurred (von Briel et al., 2018). In the new entrepreneurial environment, how can entrepreneurial organizations deal with uncertain challenges and capture business opportunities to form new digital venture ideas? The following sections will conduct an indepth analysis from the micro level entrepreneurial action perspective and construct the theoretical model of this paper, which shows in figure 1 .

\section{RESEARCH HYPOTHESIS}

\section{NETWORKING CAPABILITIES AND NEW DIGITAL VENTURE IDEAS}

The start and growth of new ventures not only rely on internal resources and capabilities, but also need to continuously develop new relationships with different roles in the market to obtain external knowledge and business information (Zou et al., 2010). Especially in the initial stage of entrepreneurship, collecting a large amount of external information is crucial for entrepreneurs to make decisions about entrepreneurial vision. The process of collecting information relies on the entrepreneur's social capital (Hills et al., 1997), and networking capabilities are key capabilities for entrepreneurs to build social relationships. As a special type of non-transferable resource, networking capabilities can improve the efficiency and effectiveness of an enterprise's access to external resources (Eisenhardt \& Martin, 2000; Teece et al., 1997; Covin et al., 2000), especially information resources. Therefore, networking capabilities help companies complete their entrepreneurial decisions in the initial stage of entrepreneurship by acquiring external information resources and improving the conversion efficiency of resource value, and new venture ideas is one of the important decisions at this stage.

The digital technologies that support the new digital venture ideas and the expected products are open and distributable, which makes cross-institutional acquisition of digital technologies possible (Kallinikos et al., 2013; Wang et al., 2007; Yoo et al., 2010). The massive and easily accessible 
information brought by the open source community has a huge impact on the entrepreneurial process. As core capabilities in the innovation process, networking capabilities are used to establish and manage social relationships through coordination, partner information, and internal communication, which is conducive to the development of cross-organizational border activities (Walter et al., 2006). In addition, networking capabilities can also promote technological innovation (Ritter \& Gemünden, 2004) and strengthen the company's understanding of customer needs to match entrepreneurial creativity with market needs (Walter et al., 2006), which is important for realizing the business value of new venture ideas. Therefore, networking capabilities are an important tool for start-ups to acquire resources and identify business opportunities (Burt, 1997; Hitt \& Ireland, 2000). Furthermore, in the digital environment, entrepreneurs can also use the coordination of networking capabilities to build social relationships across fields, search for required digital information or human resources, and use digital technology in the process of generating new digital venture ideas with technology partners. Based on the previous description, this article proposes:

H1: In the context of digitalization, networking capabilities have a positive effect on the formation of new digital venture ideas.

\section{IT CAPABILITIES AND NEW DIGITAL VENTURE IDEAS}

In the digital environment of innovation and information sharing, IT capabilities refers to ability to manage, integrate, and coordinate IT resources (IT infrastructure, IT human resources, IT business experience, etc.) (Bharadwaj, 2000) and other resources for value creation and upgrading (Lu \& Ramamurthy, 2011). IT capabilities is a core competitive advantage in the digital era (Wade \& Hulland, 2004). Especially for start-ups, product/service differentiation and cost advantages brought by IT capabilities provide huge potential for start-ups to enter the market for the first time. In addition, IT capabilities also have a significant positive effect on IT technology-based ventures (Zhang \& Sarker, 2008), which is essential for identifying business opportunities in the digital environment (Shane \& Venkataraman, 2000) and generating new venture ideas. Specifically, IT capabilities can be divided into three sub-dimensions: IT infrastructure capability, IT proactive stance, and IT business spanning capability (Lu \& Ramamurthy, 2011).

Firstly, IT infrastructure capability reflects the company's ability to manage data and architecture, network communication services and application programs (Ross et al., 1996; Weill et al., 2002). Digitalization has changed ways of social interaction, and users share information online (Greenstein et al., 2013). The IT infrastructure capability can monitor market trends and consumer behavior (Mithas et al., 2005). With IT infrastructure capability, companies can capture product/service information on digital platforms and identify customer needs in a timely and low-cost manner via effective digital communication (Greenstein et al., 2013). In addition, IT infrastructure capability can also collaborate with external business units to explore opportunities, which is critical to technological innovation and formation of new venture ideas (Bharadwaj, 2000).

Secondly, IT business spanning capability is a management capability that anticipates and utilizes IT resources to support and strengthen business goals (Bharadwaj, 2000; Ross et al., 1996; Wade $\&$ Hulland, 2004). On the one hand, IT business spanning capability enhances business partnership and corporation by integrating IT functions and other functions within the enterprise. In the digital environment, the intersection of IT capabilities and other professional fields helps to integrate information flow, capital flow, and other resources (Rai et al., 2006), in particular, the integration of multiple areas/information from different business departments helps to stimulate new venture ideas (Mumford et al., 1996); On the other hand, as a predictive ability, IT business spanning capability can also predict future technological changes and directions, and then adapt to these changes through construction network platforms (Wade \& Hulland, 2004). Organizations with this ability can predict the direction of future technology development, which will help to match new digital venture ideas with 
market needs. In addition, IT business spanning capability can also coordinate IT-related resources, skills, and knowledge to help companies to achieve the expected business goals of new venture ideas (Stoel \& Muhanna, 2009). In summary, in the digital environment, IT business spanning capability has great effect on generating new digital venture ideas.

Lastly, IT proactive stance is the ability to actively search for new methods to achieve IT innovation, or use existing IT resources to create business opportunities (Weill et al., 2002). Organizations with this ability are always looking for new ways to use and develop IT resources to create business opportunities (Schumpeter, 2017; Drucker, 2014). New venture idea is a subjective construction of entrepreneurial opportunities, which is considered as a key driver of entrepreneurial action (Alvarez \& Barney, 2001; Bergmann, 2017; Kornish \& Ulrich, 2011). Therefore, IT proactive stance helps to generate new digital venture ideas in the digital environment. In summary, this article proposes:

H2: IT capabilities (IT infrastructure capability, IT proactive stance, IT business spanning capability) have a positive effect on the generation of new digital venture ideas.

\section{THE MODERATING EFFECT OF PRIOR KNOWLEDGE}

As an important human capital, prior knowledge, such as prior knowledge of industry (Shane \& Venkataraman, 2000), market and customer issues, can help firms recognize and exploit opportunities (Marvel \& Lumpkin, 2007). Particularly, as a combination of experience, market information, and knowledge of customer problems (Davenport \& Prusak, 1998), prior knowledge plays an important role in the initial stage of entrepreneurship (Shepherd \& Patzelt, 2018). In the initial preparation stage of the process of finding and discovering opportunities (Fiet, 2007), prior knowledge is used as a schema for individuals to interpret information (Gaglio \& Winter, 2009). Prior knowledge affects the search and association of new information, guides the exploration of valuable information and new opportunities and furtherly affects decision making (Hajizadeh \& Zali, 2016). Therefore, prior knowledge has an important role in the initial stage of entrepreneurship.

\section{PRIOR KNOWLEDGE, NETWORKING ABILITY, NEW DIGITAL VENTURE IDEAS}

All types of entrepreneurship are based on resource development and building new capabilities to seek opportunities (Stopford \& Baden-Fuller, 1994). Networking capability, as an important ability for entrepreneurs to build social relationships, is an important means for them to join the external network. In the digital entrepreneurial environment, enterprises or entrepreneurs cannot be considered as independent roles (Zaheer et al., 2010), and their entrepreneurial activities involve a global network of stakeholders. In this digital environment, information technology has a great impact on networking capability (Zhang et al., 2009). Information technology can help individuals or organizations build new social relationships without limitations of time and place, which is essential for capturing resources and opportunities. Therefore, prior knowledge of information technology plays a crucial role in enhancing entrepreneurs' networking ability to build social relationships in global value chains. Furthermore, prior knowledge also helps to identify opportunities in this collaborative network relationship (McGrath \& OToole, 2013). Prior knowledge about market and customer problems helps to identify more innovative opportunities (Hajizadeh \& Zali, 2016), which has a positive impact on the formation of new digital venture ideas. In the digital environment, there is a huge amount of information in external networks. With huge amount of digital information, how to identify and use valuable information is important for the generation of new digital venture ideas. Prior knowledge, as a combination of experience, market information, and knowledge of customer problems (Davenport \& Prusak, 1998), plays an active guiding role in the process of capturing information in external networks based on network capabilities. Therefore, in the context of digitalization, the combination of high-quality prior knowledge and networking capabilities for acquisition of social capital is more 


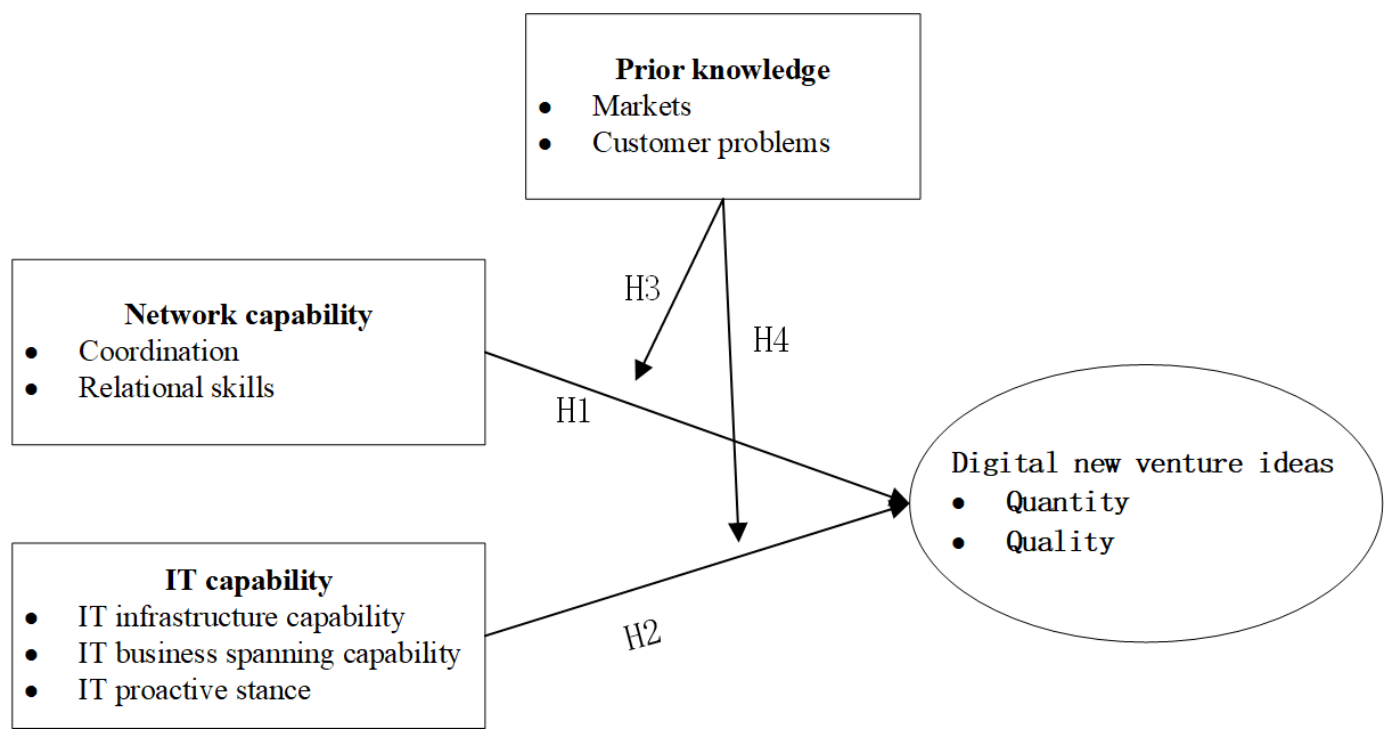

beneficial to the generation of new digital venture ideas (Gish et al., 2019). In conclusion, this article believes that:

H3: Prior knowledge has a positive moderating effect on the relationship between networking capabilities and new digital venture ideas.

\section{PRIOR KNOWLEDGE, IT CAPABILITIES, NEW DIGITAL VENTURE IDEAS}

Shepherd and DeTienne (2005) believe that individuals with prior knowledge can effectively find and use the value of existing information, so they can identify more business opportunities. Prior knowledge about technology and markets is considered one of the prerequisites for identifying entrepreneurial opportunities (Marvel \& Lumpkin, 2007). Other types of prior knowledge, such as industry experience, education, etc., help to analyze and use newly acquired information (Grégoire et al., 2010), and play an important role in matching technologies and market demand. In particular, prior knowledge about customer problems, market, and technical capabilities can facilitate the formation of new venture ideas and the marketization of these ideas (Amabile, 1999). Therefore, the prior knowledge in other professional fields can promote the commercialization of technical resources with IT capabilities, which plays an important role in the formation of new digital venture ideas with market potential.

H4: Prior knowledge has a positive moderating effect on the relationship between IT capabilities and new digital venture ideas.

\section{RESEARCH METHODS}

\section{RESEARCH DESIGN AND DATA COLLECTION}

The collection of sample data in this study uses both offline and online methods. These samples are randomly distributed in different regions of China and have different entrepreneurial experiences. There 
are three main sources of data: 1) surveying alumni who work in a startup company using researchers' alumni network; 2) conducting filed surveys in different locations: Harbin, Changchun, Shenyang, and Dalian; 3) conducting online surveys in Beijing, Zhengzhou, Zhejiang, and Shenzhen, and communicating with corporate survey participants mainly through telephone and email. We distributed a total of 457 questionnaires and get 390 responses. After screening, 278 valid questionnaires were finally obtained. The total effective rate of the questionnaires was $71.28 \%$. Among them, $61.2 \%$ of the participants were male, $50.7 \%$ were under 30 years old, $23.7 \%$ were $30-34$ years old, $12.6 \%$ were $35-39$ years old, $7.2 \%$ were $40-45$ years old, and $5.8 \%$ were over 45 years old. In addition, all participants have at least college education (3.6\% were junior colleges, $35.3 \%$ were undergraduates, $47.1 \%$ were masters, and $14 \%$ were doctors), and have different entrepreneurial experience ( 0 time accounted for $66.9 \%, 1$ time accounted for $20.9 \%, 2$ times accounted for $6.8 \%, 3$ times or more accounted for $5.4 \%$ ).

Looking for entrepreneurs to review the previous process of new digital venture ideas faces many methodological challenges (Kier \& McMullen, 2018), such as retrospective bias (Aaker et al., 2008), attribute bias (Fiske \& Taylor, 1991), and self-reporting bias (Sandberg \& Hofer, 1987). Therefore, in order to avoid bias, we adopted a quasi-experimental method (Corbett, 2007; Mueller \& Shepherd, 2014). During the research process, participants were asked to generate new digital venture ideas based on a single basic digital technology (Kier \& McMullen, 2018). The digital technology used in this article is facial recognition technology. Participants were required to put forward as many entrepreneurial ideas as possible based on the description of the technology in the questionnaire. Participants were informed "There is no right or wrong answer to any question. All answers are only used for academic research, please answer honestly." Drawing on the research of Kier \& McMullen (2018) and von Briel et al. (2018), this paper divides new digital venture ideas into two sub-dimensions, the quantity of new digital venture ideas and the quality of new digital venture ideas. After the survey, we invited two experts in the field to independently rate the number of new digital venture ideas (Kier \& McMullen, 2018). This rating is used to measure the quantity of new digital venture idea. In addition, after participants put forward some digital venture ideas, we asked them to choose the best venture idea and briefly describe it. Then we asked two experts in the entrepreneurial field to independently rate the originality (Gielnik et al., 2012) and the practicality (Poetz \& Schreier, 2012) of this venture idea. The ratings of originality and practicality are used to measure the quality of new digital venture idea. The measure of originality ranges from 1 (boring business idea) to 5 (surprising business idea). The measure of practicality ranges from 1 (low feasibility) to 5 (high feasibility). This paper uses intra-class correlation coefficients to measure the reliability of the quality about new digital venture ideas (Grégoire et al., 2015; Mueller \& Shepherd, 2014). The consistency is strong when ICC is between 0.6-0.8 (Fleiss \& Cohen, 2016). In this paper, the ICC of the originality and practicality of the new digital venture idea is 0.683 , and the Cronbach Alpha is 0.811 , indicating that the quality of the new digital venture idea has good reliability.

There may be common method biases in the research process, which can easily lead to that a single factor explains most of the variance (Podsakoff \& Organ, 1986) and will eventually make the research conclusions unstable. For this reason, the Harman single factor method is used to solve this problem, that is, to do a factor analysis of the entire questionnaire. Without rotation, the first factor explains the variance of 39.705, and there is no single factor explaining most of the variance. So, the common method variance problem has little impact on subsequent analysis. In addition, when the answers to valid questionnaires and invalid questionnaires are biased, nonresponse bias problems will occur (Lambert \& Harrington, 1990). Thus, we conducted t-tests on 278 valid questionnaires and 112 invalid questionnaires, and all $\mathrm{t}$ values showed non-significance $(\mathrm{p}>0.05)$. 


\section{VARIABLE MEASUREMENT}

\section{NETWORKING CAPABILITY}

We measure networking capability by using two dimensions: relational skills and internal communication (Walter et al., 2006). Each dimension includes 3 measure indicators. Because the goal of this paper is to analyze the impact of networking capability on new digital venture ideas, the 6 indicators are directly used to measure the networking capability. Each indicator has a 5-point scale (from 1 "completely dissatisfied" to 5 "fully satisfied").

\section{IT CAPABILITIES}

We measure IT capabilities by using three sub-dimensions: IT infrastructure capability, IT proactive stance, and IT business spanning capability (Lu \& Ramamurthy, 2011). IT infrastructure capability and IT proactive stance are measured using 3 indicators respectively. IT business spanning capability is measured using 4 indicators. Because the goal of this paper is to analyze the impact of IT capabilities on new digital venture ideas, all 10 indicators are used directly to measure IT capabilities. Each indicator has a 5-point scale (from 1 "poorer than most" to 5 "superior to most").

\section{PROPR KNOWLEDGE}

Prior knowledge is measured using two sub-dimensions: prior knowledge of ways to serve markets and prior knowledge of customer problems (Marvel \& Lumpkin, 2007). Prior knowledge of ways to serve markets is measured using 4 indicators. Prior knowledge of customer problems is measured using 3 indicators. Because the goal of this paper is to analyze the impact of prior knowledge on new digital venture ideas, all 7 indicators are directly used to measure prior knowledge. Each indicator has a 5-point scale (from 1 "completely dissatisfied" to 5 "fully satisfied").

\section{CONTROL VARIABLES}

Bernerth \& Aguinis (2016) and Kier \& Mcmullen (2018) believe that adding control variables to the model can effectively control the impact of endogenous factors on dependent variables. Entrepreneurial experience (Westhead, 1995), age (Cressy \& Storey, 1995), and education background (Davidsson \& Honig, 2003) are important human capitals, which have an important influence on the entrepreneurial process (Davidsson \& Honig, 2003; Wiklund \& Shepherd, 2008). So, we set those as control variables. In addition, we also controlled the influence of gender, with code 0 representing males and code 1 representing females.

This paper uses exploratory factor analysis to evaluate the validity of the scale. The results are shown in Table 1 . The results show that the CR values of all variables are greater than 0.7 , and the AVE of factors are greater than 0.5 , indicating that the validity of the entire scale is good. In addition, the Cronbach $\alpha$ of all variables are greater than 0.7 , it shows good reliability and validity of the scale.

\section{RESULTS}

Before hypothesis testing, a preliminary test of the pairwise correlation of variables is required. The results are shown in Table 2 . The correlation coefficient results show that all variables have different degrees of correlation, and the correlation coefficients are all less than the critical value of 0.7. The research variables of network ability, IT ability and prior knowledge are significantly positively correlated with new digital venture ideas. 
Table 1. Validity and Reliability of Construct Measures

\begin{tabular}{|c|c|c|c|c|c|}
\hline Construct & Item & $\begin{array}{l}\text { Factor } \\
\text { loading }\end{array}$ & AVE & CR & $\begin{array}{c}\text { Cronbach } \\
\alpha\end{array}$ \\
\hline $\begin{array}{l}\text { Network } \\
\text { capability }\end{array}$ & $\begin{array}{l}\text { 1.We can put ourselves in our partners' position. } \\
\text { 2. We can deal flexibly with our partners. } \\
\text { 3.We almost always solve problems constructively with our partners. } \\
\text { 4.In our organization communication is often across projects and subject areas. } \\
\text { 5.In our organization managers and employees do give intensive feedback on each other. } \\
\text { 6.In our organization information is often spontaneously exchanged. }\end{array}$ & $\begin{array}{l}0.648 \\
0.727 \\
0.736 \\
0.667 \\
0.757 \\
0.730\end{array}$ & 0.506 & 0.860 & 0.833 \\
\hline IT capability & $\begin{array}{l}\text { 1.Data management services \& architectures (e.g., databases, data availability, storage, accessibility, sharing } \\
\text { etc.). } \\
\text { 2.Application portfolio \& s==ervices (e.g., ERP, ASP, reusable software modules/components, emerging } \\
\text { technologies, etc.). } \\
\text { 3.IT facilities' operations/services (e.g., servers, large-scale processors, performance monitors, etc.). } \\
\text { 4.Developing a clear vision regarding how IT contributes to business value. } \\
\text { 5.Integrating business strategic planning and IT planning. } \\
\text { 6.Enabling functional area and general management's ability to understand value of IT investments. } \\
\text { 7.Establishing an effective and flexible IT planning process and developing a robust IT plan. } \\
\text { 8. We are capable of and continue to experiment with new IT as necessary. } \\
\text { 9.We have a climate that is supportive of trying out new ways of using IT. } \\
\text { 10.We constantly seek new ways to enhance the effectiveness of IT use. }\end{array}$ & $\begin{array}{l}0.692 \\
0.726 \\
0.707 \\
0.825 \\
0.808 \\
0.781 \\
0.825 \\
0.812 \\
0.811 \\
0.804\end{array}$ & 0.609 & 0.940 & 0.941 \\
\hline $\begin{array}{l}\text { Prior } \\
\text { knowledge }\end{array}$ & $\begin{array}{l}\text { 1.My hands-on experiences in creating products/services similar to my forthcoming business. } \\
\text { 2.My knowledge of ways to produce products/services similar to that of my forthcoming product/service. } \\
\text { 3.My knowledge of products/services similar to that of my forthcoming business. } \\
\text { 4.My knowledge of specific standards that my forthcoming product/service would need to meet. } \\
\text { 5.My knowledge of ways customers use products/services similar to that of my forthcoming business. } \\
\text { 6.My first-hand interactions with customers similar to that of my forthcoming business. } \\
\text { 7.My knowledge of lead customers similar to that of my forthcoming business. }\end{array}$ & $\begin{array}{l}0.726 \\
0.744 \\
0.701 \\
0.701 \\
0.765 \\
0.707 \\
0.655\end{array}$ & 0.511 & 0.880 & 0.887 \\
\hline
\end{tabular}

This paper uses the hierarchical multiple linear regression method to verify the model. The model in this paper has moderating effect test, so variables are zero centered and control variables are introduced (Cohen et al., 2003; Hayes, 2013). The variance inflation factor VIF of all variables are tested. All VIF values are between 1.091 and 1.442, which are less than 10, indicating that there is no multicollinearity problem.

From Model 1 and Model 2, we can see that both networking capabilities $(\beta=0.367, p<0.01)$ and IT capabilities $(\beta=0.340, \mathrm{p}<0.001)$ have a significant positive impact on the quantity of new digital venture ideas. From Model 7 and Model 8 , we can see that both networking capabilities $(\beta=0.356$, $\mathrm{p}<0.001)$ and IT capabilities $(\beta=0.282, \mathrm{p}<0.001)$ have a significant positive impact on the quality of new digital venture ideas. Therefore, networking capabilities and IT capabilities have a significant positive impact on the generation of new digital venture ideas, and hypothesis 1 and hypothesis 2

Table 2. Descriptive Statistics and Correlations

\begin{tabular}{|c|c|c|c|c|c|c|c|c|c|c|c|}
\hline Variable & Mean & SD & ITC & $\mathrm{NC}$ & PK & DNVI1 & DNVI2 & Gender & Age & Education & $\begin{array}{c}\text { Startup } \\
\text { experience }\end{array}$ \\
\hline 1.ITC & 3.27 & 0.805 & 1 & & & & & & & & \\
\hline 2.NC & 3.760 & 0.632 & $0.300 * *$ & 1 & & & & & & & \\
\hline 3.PK & 3.615 & 0.619 & $0.514 * *$ & $0.499 * *$ & 1 & & & & & & \\
\hline 4.DNVI1 & 1.49 & 0.662 & $0.408 * *$ & $0.340^{* *}$ & $0.545^{* *}$ & 1 & & & & & \\
\hline 5.DNVI2 & 2.619 & 0.540 & $0.416^{* *}$ & $0.426^{* * *}$ & $0.600^{* *}$ & $0.351 * *$ & 1 & & & & \\
\hline 5.Gender & 1.388 & 0.488 & 0.001 & 0.072 & 0.005 & -0.081 & 0.078 & 1 & & & \\
\hline 6.Age & 1.935 & 1.20 & $-0.161 * *$ & -0.102 & $-0.143^{*}$ & -0.001 & -0.094 & $-0.185^{* *}$ & 1 & & \\
\hline 7.Education & 3.716 & 0.747 & 0.027 & 0.004 & 0.063 & 0.029 & 0.026 & 0.056 & $0.306^{* *}$ & 1 & - \\
\hline $\begin{array}{l}\text { 8.Startup } \\
\text { experience }\end{array}$ & 1.507 & 0.844 & $-0.171^{*}$ & 0.023 & $-0.134 *$ & -0.048 & -0.034 & $-0.252^{* *}$ & $0.357^{* *}$ & -0.063 & 1 \\
\hline
\end{tabular}

Note: 1. ITC refers to IT capability, NC refers to network ability, PK refers to prior knowledge, DNVI1 refers to the number of digital entrepreneurship ideas, and DNVI2 refers to the quality of digital entrepreneurship ideas.

2. ${ }^{*} p<0.1,{ }^{* *} p<0.05,{ }^{* * *} p<0.01$. 
proposed in this article have been verified. In the context of digitalization, networking capabilities enable entrepreneurs to establish external network connections in global value chains and create new digital venture ideas, and IT capabilities provide technical support for startups to acquire and utilize digital resources.

From the results of Model 5 and Model 11, we see that 1) the interactive effect of prior knowledge and networking ability $(\beta=0.119, \mathrm{p}<0.05)$ is significantly positively correlated with the quantity of new digital venture ideas; 2$)$ the interactive effect of prior knowledge and network ability $(\beta=0.109, p<0.05)$ is significantly positively correlated with the quality of new digital venture ideas. Therefore, prior knowledge has a positive moderating effect on the relationship between networking capabilities and new digital venture ideas, and hypothesis 3 proposed in this paper has been verified. As an integration of experience, market and customer problems information, prior knowledge guides the process of interpreting and capturing external information. In the context of digitalization, rich prior knowledge helps entrepreneurs to identify important potential partners in the global entrepreneurship network.

In hypothesis 4, this paper assumes that prior knowledge has a positive moderating effect on the relationship between IT capabilities and new digital venture ideas. From Model 6 and Model 12, we can conclude that 1$)$ the interactive effect of prior knowledge and IT ability $(\beta=0.099, p<0.05)$ is significantly positively correlated with the quantity of new digital venture ideas; and 2 ) the interactive effect of prior knowledge and IT ability $(\beta=0.077, \mathrm{p}<0.05)$ is significantly positively correlated with the quality of new digital venture ideas. Therefore, hypothesis 4 of this article has been verified.

Table 3. Results of Regression Analysis

\begin{tabular}{|c|c|c|c|c|c|c|c|c|c|c|c|c|}
\hline \multirow{3}{*}{ Variable } & \multicolumn{12}{|c|}{ New digital venture idea generation } \\
\hline & \multicolumn{6}{|c|}{ New digital venture idea quantity } & \multicolumn{6}{|c|}{ New digital venture idea quality } \\
\hline & Model1 & Model2 & Model3 & Model4 & Model5 & Model6 & Model7 & Model8 & Model9 & Model10 & Model11 & Model12 \\
\hline \multicolumn{13}{|l|}{$\begin{array}{l}\text { Independent } \\
\text { variables }\end{array}$} \\
\hline $\mathrm{NC}$ & $0.367 * * *$ & & 0.107 & $0.124^{*}$ & & & $0.356^{* * * *}$ & & $0.134 * *$ & & $0.150^{* * *}$ & \\
\hline ITC & & $0.340 * * *$ & & & $0.151^{* *}$ & $0.136^{* *}$ & & $0.282 * * *$ & & $0.106^{* * *}$ & & $0.095^{*}$ \\
\hline \multicolumn{13}{|l|}{ Mediator } \\
\hline PK & & & $0.540^{* * * *}$ & $0.549 * * * *$ & $0.499^{* * * *}$ & $0.526^{* * *}$ & & & $0.461^{* * * *}$ & $0.462^{* * *}$ & $0.469^{* * *}$ & $0.389^{* * * *}$ \\
\hline $\mathrm{NC} * \mathrm{PK}$ & & & & $0.119^{*}$ & & & & & & & $0.109^{*}$ & \\
\hline $\mathrm{ITC} * \mathrm{PK}$ & & & & & & $0.099^{*}$ & & & & & & $0.077^{*}$ \\
\hline \multicolumn{13}{|l|}{ Controls } \\
\hline Gender & $-0.164^{*}$ & -0.101 & -0.110 & -0.111 & -0.089 & -0.083 & 0.041 & 0.097 & 0.087 & $0.108^{*}$ & 0.086 & $0.112 *$ \\
\hline Age & 0.020 & 0.032 & 0.048 & 0.047 & 0.053 & 0.050 & -0.027 & -0.021 & -0.004 & -0.002 & -0.005 & -0.003 \\
\hline Education & 0.016 & 0.003 & -0.024 & -0.024 & -0.028 & -0.022 & 0.030 & 0.021 & -0.041 & -0.008 & -0.004 & -0.003 \\
\hline $\begin{array}{l}\text { Startup } \\
\text { experience }\end{array}$ & -0.065 & -0.013 & -0.024 & -0.029 & -0.005 & 0.001 & 0.006 & 0.050 & 0.134 & 0.058 & 0.036 & $0.062 *$ \\
\hline Sample size & 278 & 278 & 278 & 278 & 278 & 278 & 278 & 278 & 278 & 278 & 278 & 278 \\
\hline $\mathrm{R}^{2}$ & 0.133 & 0.176 & 0.317 & 0.327 & 0.334 & 0.343 & 0.187 & 0.184 & 0.389 & 0.388 & 0.402 & 0.397 \\
\hline Adjust $R^{2}$ & 0.117 & 0.160 & 0.302 & 0.310 & 0.319 & 0.326 & 0.172 & 0.169 & 0.375 & 0.375 & 0.386 & 0.382 \\
\hline$F$ value & 8.368 & 11.590 & 20.967 & $\begin{array}{l}18.770 \\
p=0.000\end{array}$ & 22.608 & 20.178 & 12.527 & 12.304 & 28.704 & 28.689 & 25.890 & 25.422 \\
\hline
\end{tabular}

Note:1. Coefficients are unstandardized.

2. Gender was coded $0=$ male, $1=$ female.

3. ${ }^{*} p<0.05,{ }^{* *} p<0.01,{ }^{* * *}<0.001$. 
Prior knowledge of market information and customer problems can help to match IT technology and market demand, which is important for the formation of new venture ideas and the marketization of these ideas.

\section{CONCLUSION}

Digital technologies have been widely used in all aspects of the entrepreneurship. The impact of digital technologies on the development and use of new venture ideas cannot be ignored (Nambisan, 2017; Von Briel et al., 2018), giving rise to an emerging concept of digital venture ideas. Existing research on new digital venture ideas have explored the impact of digital technology as an external mechanism on the formation of new venture ideas (Chalmers et al., 2019; von Briel et al., 2018). Compared with the traditional entrepreneurship, digital technology has blurred the boundaries of the participants and the process of generating venture ideas. However, there are few papers that explore how entrepreneurial organizations respond to major changes brought by digital technologies (von Briel et al., 2018). Therefore, how startups should deal with high-uncertainty challenges and capture business opportunities to form new digital venture ideas needs further exploration.

Based on the theoretical review of the existing literature, with focus on the micro level entrepreneurial actions, this paper explores: 1) the impact of networking capabilities and IT capabilities on the generation of new digital venture ideas in the digital environment; and 2) the role of prior knowledge. The research finds that: first, in the context of digitalization, stronger networking capabilities and IT capabilities are more beneficial for startups to form new digital venture ideas. Networking capabilities can help startups build new global social relationships without limitations of time and place, which is essential for capturing resources and opportunities. IT capabilities can help startups make use of the digital information and other resources of the open source community in the process of building new digital venture ideas; second, prior knowledge has a positive moderating effect on the relationship between networking capabilities and new digital venture ideas. In the digital environment, prior knowledge, as an integration of experience, entrepreneurial information, and professional perspectives, helps entrepreneurs to identify valuable information from the massive digital information.

This paper makes several contributions to the literature. First, existing research only define the concept and features of digital new venture idea, this paper uses a combination of theoretical and empirical analysis to explore how startups can build new digital venture ideas in the context of digitalization, it responds some scholars' call for empirical research for digital new venture idea (von Briel et al., 2018). Second, based on the new digital entrepreneurial context, this paper explores the impact of networking capabilities, IT capabilities, and prior knowledge on the generation of new digital venture ideas, which contributes to researches on capabilities and entrepreneurial cognition. Third, the existing research on digital entrepreneurship is still in the initial stage of theoretical research, multiple researches for exploratory entrepreneurial action in digital context are urgently needed. The exploration of the factors that influence the formation of new digital venture ideas in this paper has further enriched the research on digital entrepreneurship, which is also of great significance to the entire entrepreneurial research.

\section{RESEARCH LIMITATIONS AND FUTURE WORK}

Although this paper makes several contributions to the current literature, there are some research limitations as well. First, the samples in this article are mainly from China. We can extend the established theoretical framework for more regions in the future. Second, research is limited to only using cross-sectional data to verify the theoretical model of this paper. In the future, we can use dynamic research methods to verify the influence of networking capabilities, IT capabilities, and prior knowledge on new digital venture ideas, because the networking capabilities, IT capabilities, and prior 
knowledge can be obtained during long-term accumulation process. Last, this paper explores only the impact of networking capabilities, IT capabilities and prior knowledge on new digital venture ideas. Some research has proposed that entrepreneurial cognition (Frederiks et al., 2019), entrepreneurial imagination (Kier \& Mcmullen, 2018), and entrepreneur traits (Dimov, 2007) have an important influence on the formation of new venture ideas. Therefore, in the context of digitalization, we can further explore whether these factors still affect the formation of new digital venture ideas in the future.

\section{ACKNOWLEDGMENT}

This research was supported by the National Science Foundation of China (71972083, 71620107001) and Dalian University of Technology Fundamental Research Fund (DUT19RW107). 


\section{REFERENCES}

Aaker, D. A., Kumar, V., \& Day, G. S. (Eds.). (2008). Marketing research. John Wiley \& Sons.

Aceto, G., Persico, V., \& Pescapé, A. (2020). Industry 4.0 and health: Internet of things, big data, and cloud computing for healthcare 4.0. Journal of Industrial Information Integration, 18, 100129. doi:10.1016/j. jii.2020.100129

Adler, P. S., \& Kwon, S. W. (2002). Social capital: Prospects for a new concept. Academy of Management Review, 27(1), 17-40. doi:10.5465/amr.2002.5922314

Alvarez, S., \& Barney, J. (2001). How entrepreneurial firms can benefit from alliances with large partners? The Academy of Management Executive, 15(1), 139-148. doi:10.5465/ame.2001.4251563

Amabile, T. (1998). How to kill creativity. Harvard Business Review, 76(5), 76-87. PMID:10185433

Bergmann, H. (2017). The formation of opportunity beliefs among university entrepreneurs: An empirical study of research-and non-research-driven venture ideas. The Journal of Technology Transfer, 42(1), 116-140. doi:10.1007/s10961-015-9458-z

Bernerth, J. B., \& Aguinis, H. (2016). A critical review and best-practice recommendations for control variable usage. Personnel Psychology, 69(1), 229-283. doi:10.1111/peps.12103

Bharadwaj, J. A. S. A. (2000). Resource-based perspective on information technology capability and firm performance: An empirical investigation. Management Information Systems Quarterly, 24(1), 169-196. doi: $10.2307 / 3250983$

Blohm, I., Leimeister, J. M., \& Krcmar, H. (2013). Crowdsourcing: How to benefit from (too) many great ideas. MIS Quarterly Executive, 12(4), 199-211.

Burt, R. S. (1997). The contingent value of social capital. Administrative Science Quarterly, 42(2), 339-365. doi: $10.2307 / 2393923$

Chalmers, D., Matthews, R., \& Hyslop, A. (2019). Blockchain as an external enabler of new venture ideas: Digital entrepreneurs and the disintermediation of the global music industry. Journal of Business Research. Advance online publication. doi:10.1016/j.jbusres.2019.09.002

Cohen, J., Cohen, P., West, S. G., \& Aiken, L. S. (2003). Applied multiple regression/correlation analysis for the behavioral sciences. Lawrence Erlbaum.

Corbett, A. C. (2007). Learning asymmetries and the discovery of entrepreneurial opportunities. Journal of Business Venturing, 22(1), 97-118. doi:10.1016/j.jbusvent.2005.10.001

Covin, J. G., Slevin, D. P., \& Heeley, M. B. (2000). Pioneers and followers: Competitive tactics, environment, and firm growth. Journal of Business Venturing, 15(2), 175-210. doi:10.1016/S0883-9026(98)00015-9

Cressy, R., \& Storey, D. (1995). New firms and their bank. National Westminster Bank PLC.

Davenport, T. H., \& Prusak, L. (Eds.). (1998). Working knowledge: How organizations manage what they know. Harvard Business Press.

Davidsson, P. (2015). Entrepreneurial opportunities and the entrepreneurship nexus: A reconceptualization. Journal of Business Venturing, 30(5), 674-695. doi:10.1016/j.jbusvent.2015.01.002

Davidsson, P., \& Honig, B. (2003). The role of social and human capital among nascent entrepreneurs. Journal of Business Venturing, 18(3), 301-331. doi:10.1016/S0883-9026(02)00097-6

Dimov, D. (2007). Beyond the single-person, single-insight attribution in understanding entrepreneurial opportunities. Entrepreneurship Theory and Practice, 31(5), 713-731. doi:10.1111/j.1540-6520.2007.00196.x

Drucker, P. (Ed.). (2014). Innovation and entrepreneurship. Routledge. doi:10.4324/9781315747453

Eisenhardt, K. M., \& Martin, J. A. (2000). Dynamic capabilities: What are they? Strategic Management Journal, 21(10-11), 1105-1121. doi:10.1002/1097-0266(200010/11)21:10/11<1105::AID-SMJ133>3.0.CO;2-E 
Ekbia, H. R. (2009). Digital artifacts as quasi-objects: Qualification, mediation, and materiality. Journal of the American Society for Information Science and Technology, 60(12), 2554-2566. doi:10.1002/asi.21189

Fatma, N., Haleem, A., Javaid, M., \& Khan, S. (2020). Comparison of fused deposition modeling and color jet 3D printing technologies for the printing of mathematical geometries. Journal of Industrial Integration and Management, 1-13.

Fiet, J. O. (2007). A prescriptive analysis of search and discovery. Journal of Management Studies, 44(4), 592-611. doi:10.1111/j.1467-6486.2006.00671.x

Fiske, S. T., \& Taylor, S. E. (Eds.). (1991). Social cognition. McGraw-Hill.

Fleiss, J. L., \& Cohen, J. (2016). The equivalence of weighted Kappa and the intraclass correlation coefficient as measures of reliability. Educational and Psychological Measurement, 33(3), 613-619. doi:10.1177/001316447303300309

Frederiks, A. J., Englis, B. G., Ehrenhard, M. L., \& Groen, A. J. (2019). Entrepreneurial cognition and the quality of new venture ideas: An experimental approach to comparing future-oriented cognitive processes. Journal of Business Venturing, 34(2), 327-347. doi:10.1016/j.jbusvent.2018.05.007

Gaglio, C. M., \& Winter, S. (2009). Entrepreneurial alertness and opportunity identification: Where are we now? Understanding the entrepreneurial mind. Springer.

Gandhi, V., \& Singh, J. (2020). An automated review of body sensor networks research patterns and trends. Journal of Industrial Information Integration, 18, 100132. doi:10.1016/j.jii.2020.100132

Gielnik, M. M., Frese, M., Graf, J. M., \& Kampschulte, A. (2012). Creativity in the opportunity identification process and the moderating effect of diversity of information. Journal of Business Venturing, 27(5), 559-576. doi:10.1016/j.jbusvent.2011.10.003

Gish, J. J., Wagner, D. T., Grégoire, D. A., \& Barnes, C. M. (2019). Sleep and entrepreneurs' abilities to imagine and form initial beliefs about new venture ideas. Journal of Business Venturing, 34(6), 105943. doi:10.1016/j. jbusvent.2019.06.004

Greenstein, S., Lerner, J., \& Stern, S. (2013). Digitization, innovation, and copyright: What is the agenda? Strategic Organization, 11(1), 110-121. doi:10.1177/1476127012460940

Grégoire, D. A., Barr, P. S., \& Shepherd, D. A. (2010). Cognitive processes of opportunity recognition: The role of structural alignment. Organization Science, 21(2), 413-431. doi:10.1287/orsc.1090.0462

Haenlein, M., Kaplan, A., Tan, C. W., \& Zhang, P. (2019). Artificial intelligence (AI) and management analytics. Journal of Management Analytics, 6(4), 341-343. doi:10.1080/23270012.2019.1699876

Hajizadeh, A., \& Zali, M. (2016). Prior knowledge, cognitive characteristics and opportunity recognition. International Journal of Entrepreneurial Behaviour \& Research, 22(1), 63-83. doi:10.1108/IJEBR-05-2015-0110

Haleem, A., \& Javaid, M. (2019). Enablers, barriers, and critical success factors for effective adoption of colorjet 3D printing technology. Journal of Industrial Integration and Management, 1950009.

Hayes, A. F. (Ed.). (2013). An introduction to mediation, moderation, and conditional process analysis: A regression-based approach. Guilford Press.

Hills, G. E., Lumpkin, G. T., \& Singh, R. P. (1997). Opportunity recognition: Perceptions and behaviors of entrepreneurs. Frontiers of Entrepreneurship Research, 17, 168-182.

Hitt, M., \& Ireland, D. (2000). The intersection of entrepreneurship and strategic management research. The Blackwell Handbook of Entrepreneurship, 45-63.

Kallinikos, J., Aaltonen, A., \& Marton, A. (2013). The ambivalent ontology of digital artifacts. Management Information Systems Quarterly, 37(2), 357-370. doi:10.25300/MISQ/2013/37.2.02

Kier, A. S., \& Mcmullen, J. S. (2018). Entrepreneurial imaginativeness in new venture ideation. The Academy of Management Journal, 61(6).

Kornish, L. J., \& Ulrich, K. T. (2011). Opportunity spaces in innovation: Empirical analysis of large samples of ideas. Management Science, 57(1), 107-128. doi:10.1287/mnsc.1100.1247 
Lambert, D. M., \& Harrington, T. C. (1990). Measuring nonresponse bias in customer service mail surveys. Journal of Business Logistics, 11(2), 44-59.

Law, K. S., \& Chung, F. L. (2020). Knowledge-driven decision analytics for commercial banking. Journal of Management Analytics, 7(2), 209-230. doi:10.1080/23270012.2020.1734879

Lomberg, C., Kollmann, T., \& Stöckmann, C. (2017). Different styles for different needs-The effect of cognitive styles on idea generation. Creativity and Innovation Management, 26(1), 49-59. doi:10.1111/caim.12188

Lu, Y., \& Ramamurthy, K. R. (2011). Understanding the link between information technology capability and organizational agility: An empirical examination. Management Information Systems Quarterly, 35(4), 931-954. doi: $10.2307 / 41409967$

Marvel, M. R., \& Lumpkin, G. T. (2007). Technology entrepreneurs' human capital and its effects on innovation radicalness. Entrepreneurship Theory and Practice, 31(6), 807-828. doi:10.1111/j.1540-6520.2007.00209.x

McGrath, H., \& O'Toole, T. (2013). Enablers and inhibitors of the development of network capability in entrepreneurial firms: A study of the Irish micro-brewing network. Industrial Marketing Management, 42(7), 1141-1153. doi:10.1016/j.indmarman.2013.07.008

Mithas, S., Ramasubbu, N., Krishnan, M. S., \& Sambamurthy, V. (2005). Information technology infrastructure capability and firm performance: An empirical analysis. Academic Press.

Mohanty, M., \& Shankar, R. (2019). A hierarchical analytical model for performance management of integrated logistics. Journal of Management Analytics, 6(2), 173-208. doi:10.1080/23270012.2019.1608326

Mueller, B. A., \& Shepherd, D. A. (2014). Making the most of failure experiences: Exploring the relationship between business failure and the identification of business opportunities. Entrepreneurship Theory and Practice, $1-31$.

Mumford, M. D., Mobley, M. I., Uhlman, C. E., Reiter-Palmon, R., \& Doares, L. M. (1991). Process analytic models of creative capacities. Creativity Research Journal, 4(2), 91-122. doi:10.1080/10400419109534380

Nambisan, S. (2017). Digital entrepreneurship: Toward a digital technology perspective of entrepreneurship. Entrepreneurship Theory and Practice, 41(6), 1029-1055. doi:10.1111/etap.12254

Per, D., Jan, R., \& Frederik, V. B. (2018). External enablement of new venture creation: A framework. Academy of Management Perspectives.

Podsakoff, P. M., \& Organ, D. W. (1986). Self-reports in organizational research: Problems and prospects. Journal of Management, 12(4), 531-544. doi:10.1177/014920638601200408

Poetz, M. K., \& Schreier, M. (2012). The value of crowdsourcing: Can users really compete with professionals in generating new product ideas? Journal of Product Innovation Management, 29(2), 245-256. doi:10.1111/j.15405885.2011.00893.x

Rai, A., Patnayakuni, R., \& Seth, N. (2006). Firm performance impacts of digitally enabled supply chain integration capabilities. Management Information Systems Quarterly, 30(2), 225-246. doi:10.2307/25148729

Ritter, T., \& Gemünden, H. G. (2004). The impact of a company's business strategy on its technological competence, network competence and innovation success. Journal of Business Research, 57(5), 548-556. doi:10.1016/S0148-2963(02)00320-X

Ross, J. W., Beath, C. M., \& Goodhue, D. L. (1996). Develop long-term competitiveness through IT assets. Sloan Management Review, 38(1), 31.

Sandberg, W. R., \& Hofer, C. W. (1987). Improving new venture performance: The role of strategy, industry structure, and the entrepreneur. Journal of Business Venturing, 2(1), 5-28. doi:10.1016/0883-9026(87)90016-4

Schumpeter, J. A. (Ed.). (2017). Theory of Economic Development. Routledge. doi:10.4324/9781315135564

Shane, S., \& Venkataraman, S. (2000). The promise of entrepreneurship as a field of research. Academy of Management Review, 25(1), 217-226. doi:10.5465/amr.2000.2791611 
Shepherd, D. A. (2015). Party on! A call for entrepreneurship research that is more interactive, activity based, cognitively hot, compassionate, and prosocial. Journal of Business Venturing, 30(4), 489-507. doi:10.1016/j. jbusvent.2015.02.001

Shepherd, D. A., \& DeTienne, D. R. (2005). Prior knowledge, potential financial reward and opportunity identification. Entrepreneurship Theory and Practice, 1(29), 91-112. doi:10.1111/j.1540-6520.2005.00071.x

Shepherd, D. A., \& Patzelt, H. (2018). Prior knowledge and entrepreneurial cognition. entrepreneurial cognition. Palgrave Macmillan. doi:10.1007/978-3-319-71782-1

Simsek, Z., Lubatkin, M. H., Veiga, J. F., \& Dino, R. N. (2009). The role of an entrepreneurially alert information system in promoting corporate entrepreneurship. Journal of Business Research, 62(8), 810-817. doi:10.1016/j. jbusres.2008.03.002

Stevenson, H. H., \& Jarillo, J. C. (2009). A paradigm of entrepreneurship: Entrepreneurial management. Social Science Electronic Publishing, 11(5), 17-27.

Stoel, M. D., \& Muhanna, W. A. (2009). IT capabilities and firm performance: A contingency analysis of the role of industry and IT capability type. Information \& Management, 46(3), 181-189. doi:10.1016/j.im.2008.10.002

Stopford, J. M., \& Baden-Fuller, C. W. F. (1994). Creating corporate entrepreneurship. Strategic Management Journal, 15(7), 521-536. doi:10.1002/smj.4250150703

Teece, D. J., Pisano, G., \& Shuen, A. (1997). Dynamic capabilities and strategic management. Strategic Management Journal, 18(7), 509-533. doi:10.1002/(SICI)1097-0266(199708)18:7<509::AID-SMJ882>3.0.CO;2-Z

Vogel, P. (2017). From venture idea to venture opportunity. Entrepreneurship Theory and Practice, 41(6), 943-971. doi:10.1111/etap.12234

von Briel, F., Davidsson, P., \& Recker, J. (2018). Digital technologies as external enablers of new venture creation in the IT hardware sector. Entrepreneurship Theory and Practice, 42(1), 47-69. doi:10.1177/1042258717732779

von Briel, F., Recker, J., \& Davidsson, P. (2018). Not all digital venture ideas are created equal: Implications for venture creation processes. The Journal of Strategic Information Systems, 27(4), 278-295. doi:10.1016/j. jsis.2018.06.002

Wade, M., \& Hulland, J. (2004). Review: The resource-based view and information systems research: review, extension, and suggestions for future research. Management Information Systems Quarterly, 28(1), $107-142$. doi: $10.2307 / 25148626$

Walter, A., Auer, M., \& Ritter, T. (2006). The impact of network capabilities and entrepreneurial orientation on university spin-off performance. Journal of Business Venturing, 21(4), 541-567. doi:10.1016/j. jbusvent.2005.02.005

Wang, C., Xu, L., \& Peng, W. (2007). Conceptual design of remote monitoring and fault diagnosis systems. Information Systems, 32(7), 996-1004. doi:10.1016/j.is.2006.10.004

Weill, P., Subramani, M., \& Broadbent, M. (2002). Building IT infrastructure for strategic agility. MIT Sloan Management Review, 44(1), 57.

Westhead, P. (1995). Survival and employment growth contrasts between types of owner-managed high technology firms. Entrepreneurship Theory and Practice, 20(1), 5-27. doi:10.1177/104225879502000101

Wiklund, J., \& Shepherd, D. A. (2008). Portfolio entrepreneurship: Habitual and novice founders, new entry and mode of organizing. Entrepreneurship Theory and Practice, 32(4), 701-725. doi:10.1111/j.15406520.2008.00249.x

Yang, J. (2019). Cloud computing for storing and analyzing petabytes of genomic data. Journal of Industrial Information Integration, 15, 50-57. doi:10.1016/j.jii.2019.04.005

Yoo, Y., Henfridsson, O., \& Lyytinen, K. (2010). The new organizing logic of digital innovation: An agenda for information systems research. Information Systems Research, 21(4), 724-735. doi:10.1287/isre.1100.0322

Zaheer, A., Gözübüyük, R., \& Milanov, H. (2010). It's the connections: The network perspective in interorganizational research. The Academy of Management Perspectives, 24(1), 62-77. 
Zhang, M., Sarker, S., \& Sarker, S. (2008). Unpacking the effect of IT capability on the performance of export-focused SMEs: A report from China. Information Systems Journal, 18(4), 357-380. doi:10.1111/j.13652575.2008.00303.x

Zhang, M., Tansuhaj, P., \& McCullough, J. (2009). International entrepreneurial capability: The measurement and a comparison between born global firms and traditional exporters in China. Journal of International Entrepreneurship, 7(4), 292-322. doi:10.1007/s10843-009-0042-1

Zou, H., Liu, X., \& Ghauri, P. (2010). Technology capability and the internationalization strategies of new ventures. Organizations and Markets in Emerging Economies, 1(1), 100-119. doi:10.15388/omee.2010.1.1.14308

Meifang Yao is professor of Entrepreneurship and Management Accounting at School of Management Jilin University. She Got her doctoral degree from Jilin University in 2007. Her interests are entrepreneurial capability and venturing modeling of company.

Dan Ye is studying in Jilin University for a doctoral degree now. Her main research direction is digital entrepreneurship and entrepreneurship management.

Yang Gao is Professor in School of Economics and Management at the Dalian University of Technology in China. He has researched in the field of e-business management more than 10 years. He is expert in solving social problems with multi-attribute decision-making methods. He has presided multiple projects at the national level of China. As a research author, he has published many academic papers. He is also the reviewers of several international journals. Dr. Yang Gao is the corresponding author, can be contacted via: gzm@dlut.edu.cn.

Hui Shi is an Assistant Professor of the Computer Information Systems Department at Cal Poly Pomona. She received a B.S. in Computer Science and Technology from Hefei University of Technology, China, a M.S. in Computer Application Technique from Hefei University of Technology, China, and a Ph.D. in Computer Science from Old Dominion University. Her research interests include Data Mining, Big Data, Social Media Analysis, Information Visualization, Semantic Web and Computer Supported Cooperative Work.

Xianrong (Shawn) Zheng is an Assistant Professor of Information Technology, Old Dominion University, Norfolk, Virginia, United States. He received his Ph.D. degree in Computer Science from Queen's University, Canada. His research areas are Computing and Business. His research interests are Cloud Computing, Big Data, E-Commerce, and FinTech. He is a Member of Association for Computing Machinery (ACM), Institute of Electrical and Electronics Engineers (IEEE), and Association for Information Systems (AIS). Also, he is a Technical Program Committee Member of IEEE International Conference on Services Computing. 